\title{
THE DEFINITION OF RESERVES TO INCREASE MILK PRODUCTION ON THE BASIS OF FORECAST SUPPLY BALANCES
}

\section{Marina Meteleva* , Anna Sytenko}

\author{
Belgorod State Agricultural Academy named after V. Gorin, Belgorod, Russia
}

\begin{abstract}
Dairy animal industry is one of the leading industries of animal production and an important line of many agricultural enterprises activity of the Belgorod region. In essence, its efficiency and competitiveness depend on many certain features of the regional market. The research object is dairy industry in the Belgorod region. The aim of the research was to study the state of the dairy cattle in the Belgorod region and to identify the major reserves of milk production increase on the basis of expected resource balances. The research is connected with the definition of the used branch resources balance. It will allow the definition of the directions of the branch efficiency increase. The practical value of the work is based on an estimation of the branch resources which should help to define the necessary quantity of milk, sufficient for manufacture of dairy products for internal dairy consumption. The subtheme is Increase of Milk Production.
\end{abstract}

Keywords: milk production, dairy sector, consumption of milk and dairy products, forecast, balance of resources

\section{Introduction}

Developed market economy, the creation of which was the purpose of the reforms in the country, requires a developed product market, including the food market, an important component of which is the market of milk and dairy products (Ushachev, 2009).

Its further development will be largely determined by the following factors: living standards, socio-economic situation in the country, its position in the global market, the volume of imports into the domestic market, as well as the policies of federal and regional authorities with regard to agricultural producers. This support must be consistent with the policy development of the domestic dairy industry, aimed at increase of production efficiency, product quality and expanding its product range (Barteneva, 2012).

The research findings will help to improve production processes in the industry. Therefore, the aim of the research was to study the state of the dairy cattle in the Belgorod region and to identify the major reserves of milk production increase on the basis of expected resource balances.

The practical significance of the work is based on an assessment of needs for milk production, which can be obtained by the calculations of the resource balance, which in turn should help to define the necessary production of marketable milk, sufficient for production of domestic dairy industry, and the volumes of dairy products, which will provide food security of the region.

\section{Materials and methods}

As theoretical and methodological research bases, the works of scientists-economists in agricultural production sphere have been used; federal programs of agroindustrial manufacture development, scientifically-methodical works and recommendations research and educational institutions were taken into account. The complex of research methods is used in the research: a method of comparison, groupings, the analysis and synthesis, balance, and other methods.

Analytical approach supposes consideration of separate elements in the system of industry effectiveness assessment. This approach gives an opportunity to consider the direction of production development process, to set connections between separate elements. Synthesis summarizes the analysis considering the complex system phenomenon as a result of joint action of all analyzed bonds (Mamardashvili, 2004). Comparison is the earliest and the most common method of economical analysis. The horizontal as well as trend comparison methods are used in the research. The trend method gives an opportunity to determine the tempo of indicators changes to the level of the base year (Lapenkov and Sangadiev, 2000). The division of the studied mass of objects set by the quantitatively homogeneous groups is the grouping method. This method gives an opportunity to set connections between the studied indicators, to find the dependence between them, systematize the analysis results, and to sort out what is important.

Besides the listed methods, the balance method was used (Grenev, 2008). The trade balance of dairy products was made.

The balance basis is characterized by the model:

$$
F P_{\text {beg. }}+C P=S P+F P_{\text {end }}
$$

where:

$F P_{\text {beg. }} \quad$ - finished goods at the beginning of the period;

$C P^{\text {eeg. }}$ - commercial production;

$S P$ - sale of products;

$F P_{\text {end }} \quad$ - finished products at the end of the period.

The used method gave an opportunity to determine the possibilities of regional milk product market.

\section{Results and discussion}

Degree of population satisfaction with milk basically depends on the level of its production in the country. That is why there are problems of the optimum relation of the own dairy production and its delivery from the outside on both sides, at nation-wide and at inter-regional levels. Dried milk, animal oil, cheeses and products for children are still imported to Belgorod region.

The basic importers of dairy production to the Belgorod region are Germany, France, Poland, Belarus, and Ukraine. The market of milk and dairy products is an important component of the food market of any region. The success of the local milk products enterprises depends on their competitive struggle with foreign manufacturers for local market of butter and cheese.

Consumption of the specified kinds of products in Russia considerably lags behind a consumption level in the countries of Europe. The modern 
Table 1 Dynamics of the basic external parameters, used in the expected resource balance of used milk in the Belgorod region for the period till 2020

\begin{tabular}{|c|c|c|c|c|}
\hline Parameter & 2008 & 2010 & 2012 & 2020 - forecast \\
\hline Population in millions of people & 1,519 & 1,531 & 1,532 & 1,570 \\
\hline Mid-annual growth rate in \% & 0.3 & 0.4 & 0.06 & 2.5 \\
\hline Milk demand, in thousands of tons (total) & 598.5 & 603.2 & 603.6 & 618.6 \\
\hline Milk and dairy products consumption per capita in kg per year & 267 & 266 & 270 & 394 \\
\hline Mid-annual growth rate in \% & 1.5 & -0.75 & 1.1 & 45.9 \\
\hline Internal manufacture of dairy production in thousands of tons & 574 & 557.8 & 530.0 & 620 \\
\hline Mid-annual growth rate in \%, including: & 41 & -417 & -4.9 & 16.9 \\
\hline Cheese in tons & 5,112 & 4,056 & 4,596 & 20,410 \\
\hline Mid-annual growth rate in \% & 24.1 & -8.3 & 13.3 & rate of increase is unlikely \\
\hline Butter in tons & 6,807 & 6,856 & 7,660 & 7,850 \\
\hline Mid-annual growth rate in $\%$ & -8 & -10 & 11.7 & 2.5 \\
\hline Other kinds of production in thousands of tons & 179.2 & 213.9 & 263.0 & 588.7 \\
\hline
\end{tabular}

Table 2 The expected resource balance of dairy products in milk equivalent, in thousands of tons

\begin{tabular}{|l|c|c|c|}
\hline Indicators & $\mathbf{2 0 1 0}$ & $\mathbf{2 0 1 2}$ & $\mathbf{2 0 2 0}$ - forecast \\
\hline Stock at the beginning of the year & 32.3 & 34.0 & 44.5 \\
\hline Manufacture & 557.8 & 530.0 & 620 \\
\hline Delivered in the area including import & 45.4 & 73.6 & 664.5 \\
\hline Resources, total & 635.5 & 637.6 & 30.0 \\
\hline Industrial consumption & 45.9 & 44.5 & 618.6 \\
\hline Personal consumption* & 407.2 & 413.6 & 0.0 \\
\hline Losses & 0.0 & 0.0 & - \\
\hline Export to other regions and countries & 149.1 & 154.0 & 25.6 \\
\hline Stock at the end of the year & 33.3 & 25.5 & \\
\hline
\end{tabular}

* taking into account the population and mid-annual actual consumption; ** taking into account the consumption in 2020 to medical norm - $394 \mathrm{~kg}$ per capita; *** without regard to the import production in connection with Russia's WTO entry

consumption level of cheese and butter in the Czech Republic is equal accordingly $10-11$ and $4-5 \mathrm{~kg}$ respectively, in Germany $-21-22$ and $6-7 \mathrm{~kg}$. If the tendency of these dairy products' import remains, the internal market will have milk deficit for production of cheese and butter.

Balance of resources and used milk for the period till 2020 in Belgorod region is calculated. The volumes of total manufacture of milk were defined «from demand» («usage» a minus «import» a minus «stocks on the beginning of the year»), and the volume of milk used within year («milk usage») was defined as the sum of volumes of personal consumption, industrial consumption, losses, export, stocks at the end of years. Volumes of personal consumption of milk were defined on the basis of hypotheses of population dynamics and consumption per capita.

In Table 1, the dynamics of the basic external parameters, used in the expected resource balance shows the used milk in the Belgorod region for the period till 2020. It is expected that in 2020 the population will be 1,570 million people.

Consumption per capita was calculated considering rational norm level of $394 \mathrm{~kg}$ of milk and milk products per year. In total amount of consumption per capita, three groups of dairy products were defined:

$\square$ Cheese (the norm of consumption per capita was calculated taking into account that in 2020, it will reach 12-13 kg a year).

$\square$ Butter (the norm of consumption per capita was calculated taking into account that in 2020, it will reach $5 \mathrm{~kg}$ a year). $\square$ Other dairy products (volumes of consumption per capita were defined as a difference between total amount of dairy products consumption per capita per year and consumption of cheese and butter in milk equivalent).

It is supposed that the Belgorod manufacturers will be able to provide $100 \%$ demand of milk and butter by 2020 . However, substantial growth of internal manufacture of cheese is unlikely; hence, negative indicators of trading balance of the given kind of a product will remain. Cheese import in resources is typical for the developed countries, but there it provides necessary variety of range, and does not have negative effect on branch efficiency, and also does not compete in the market with own manufacture production.

In Russia and in the Belgorod region in particular, cheese demand is basically connected with price level, and is defined by low consumer ability of the population. The price of cheeses realization imported from Ukraine and Belarus is much lower than at local manufacturers. Local manufacturers of cheeses are more and more focused on technologies which assume the minimum usage of natural milk. Similar tendencies can lead to prices disparity increase between producers and processers of dairy products and will influence the branch development negatively. The expected resource balance allows making an analysis of the presented parameters of dairy products in milk equivalent (Table 2).

The dynamics of industrial consumption of milk was defined taking into account the marketability growth that means reduction of milk for calves 
Table 3 Basic forecast characteristics

\begin{tabular}{|c|c|c|c|}
\hline Characteristic & 2010 & 2012 & 2020 - forecast \\
\hline Consumption of dairy products per capita provided with internal manufacture in $\mathrm{kg}$ & 266 & 270 & 394 \\
\hline Structure of personal consumption in $\%$ cheese & 0.9 & 1.1 & 3.2 \\
\hline Butter & 1.7 & 1.9 & 1.3 \\
\hline Other milk products & 97.4 & 98.8 & 95.5 \\
\hline Import share in personal consumption in \% milk products, all & 11.1 & 17.7 & $7^{*}$ \\
\hline Import structure of milk products in $\%$ cheese & 35 & 50 & 70 \\
\hline Butter & 15 & 20 & 10 \\
\hline Other milk products & 50 & 30 & 20 \\
\hline
\end{tabular}

* without regard to the import production in connection with Russia's WTO entry

(60\% per calf to the current level by 2020). Stock by the end of the year was accepted at level of $4 \%$ from all resources, and the losses were not planned.

The results of the analysis, presented in Table 3, show that by 2020, the deficit of milk and milk products is possible in the region. The export of milk products will grow ( $70 \%$ of cheese, $20 \%$ of butter, $10 \%$ of other dairy products).

Summarizing the above analysis and the demand forecast, it is possible to say that by 2020 , the milk deficit within 50 thousand tons is possible in the region (as milk resources can reach 664.7 thousand tons, and real consumption - 675 thousand tons), but at growth of cheese consumption to the European level (to $12 \mathrm{~kg}$ per year), real consumption in milk equivalent can increase by $20-30$ thousand tons, and will make 705 thousand tons.

Level of milk self-sufficiency of the region is calculated by the following correlation:

$$
\frac{\text { volume of own production } \times 100 \%}{\text { volume of real consumption }}=\frac{664.7 \times 100}{705}=94.3 \%
$$

That means that the Belgorod region will be supplied by its own milk production only by $94.3 \%$. The existing branch conditions do not give a guarantee that in the case of completion of the regional programme on animal industries development by 2020 , the area will be able to block the developing deficit but also to become an active exporter of milk and milk products into other regions.

\section{Conclusion}

The analysis and demand forecast showed that considering the increase in demand and increasing milk consumption rate (within science-based nutrition standards), there may be a shortage of milk in the region. The scenario of possible development and competitiveness of dairy industry in the Belgorod region, as well as productivity growth hypothesis of dairy herd allow us to raise the problem of need to implement all the national and regional programmes for the dairy farming development. In the case of the successful implementation of a regional programme for the development of livestock by 2020 , the region will not only cover the emerging deficit, but also become an active exporter of milk and dairy products to other regions.

Geographical boundaries of the milk and dairy products are mainly determined by supply of regional agricultural producers and by processing and trade companies.

Consequently, they can be extended in general and by certain types of goods. For the Belgorod region, it primarily concerns fat cheese, butter and whole milk products. For these types of products, market boundaries can be extended to several other regions, where deficit takes place.
The regulation of agricultural production should be developed in the same context with the reform of economic development. The strategic course of modern Russia's foreign economic policy for the effective integration into the global economy and international trade requires the prospects determination of increasing the competitiveness of agricultural products.

\section{References}

BARTENEVA, 0. D. 2012. Actual questions of modern dairy production. Barteneva. In Milk Processing, 2012, no. 7, p. 60-63.

DEIMEL, M. - THEUVSEN, L. 2011. Networking in Meat Production Systems: The Influence of Cooperative Structures on Farmers' Participation. In International journal on food system dynamics, vol. 2, 2011, no. 1, p. 1-22. Access mode: url: http://centmapress. ilb.uni-bonn.de (10.01. 13)

DEVELOPMENT PROGRAMS of Belgorod Region agriculture on 2008-2012. Electronic resource. Official website of Governour and Government of the Belgorod region. Access mode: URL: http://www.belregion.ru (10.01.13).

GRINEV, G. P. 2008. Theory of Economic Analysis. M : MIEMP, 2008. 36 p.

CHERDANTSEV, V. P. 2009. Regulation of the regional agrofood market. In V.P. Cherdantsev, Economics of agricultural and processing enterprises, 2009, no. 2, p. 41-43.

KRIJN, G. R. 2010. Business Dynamics with Scenarios on Dutch Agriculture and its Institutional Arrangements, LEI-Wageningen UR, the Netherlands, 2010. p. 176-181.

LAPENKOV, V. I. - SANGADIEV, Z. G. 2000. Techno-economic analysis of the company. Ulan-Ude : Univ ESSTU, 2000. $240 \mathrm{p}$.

MAMARDASHVILI, M. K. 2004. Processes of analysis and synthesis. url: http://soul.dn.ua/ system/files/article/mamardashvili_m.k._analiz_i_sintez.doc (10.01.13)

OTTEN, D. - VAN DEN WEGHE, H. F. A. 2011. The Sustainability of Intensive Livestock Areas (ILAS): Network System and Conflict Potential from the Perspective of Animal Farmers. In International journal on food system dynamics, vol. 2, 2011, no. 1, p. 2335. Access mode: URL: http://centmapress.ilb.uni-bonn.de (20.01. 13).

SHUTKOV, A. 2008. Provision of food stability of Russia. In Agricultural complex: economy, management, 2008, no. 6, p. 11-14.

USHACHEV, I. G. 2009. Economical growth and competitiveness of Russian agriculture: Materials of the $3^{\text {rd }}$ Russian congress of agrarian economists. In Problems of economical growth and competitiveness of Russian agriculture. Electronic resource. Report of the academician I. G. Ushachev - GNU Russian scientific-research Institute of agricultural economy of Russian agricultural academy, Moscow, 9-10 February, 2009. website. Access mode: url: http://www.vniiesh.ru (15. 12. 2012).

\section{Contacts address}

Marina Meteleva, Dr., Associate Professor of the Chair of Organization and Management, Belgorod State Agricultural Academy named after V. Gorin, ul. Vavilova 1, Mayskiy, Belgorod Region, Russia, telephone: +7 96062831 05, fax: +7 (4722) 391174, e-mail: mmg.bel.31@gmail.com 